\title{
UDC 821.161.2’05.09UKRAINKA:159.91
}

\author{
H. I. YASTRUBETSKA ${ }^{1 *}$, T. P. LEVCHUK ${ }^{2 *}$ \\ ${ }^{1 *}$ Lesya Ukrainka Volyn National University (Lutsk, Ukraine), e-mail iastrubetska.galina@vnu.edu.ua, \\ ORCID 0000-0003-1470-9232 \\ ${ }^{2 *}$ Lesya Ukrainka Volyn National University (Lutsk, Ukraine), e-mail Tereza.Levchuk@vnu.edu.ua, \\ ORCID 0000-0002-0277-3280
}

\section{Artist's Psychophysiology in Disposition to Style (Case Study of Lesia Ukrainka's Biography Materials)}

Purpose of the study is to shed light on the role of psychophysiology in the creative process, namely, the style corrections connected with pathological changes in the artist's organism, deviating from empirical-descriptive methods. Theoretical basis of the study implies the interpretation of the notions style and disease not in their narrow professional limitation but from the standpoint of expanding the parameters of these concepts to philosophical dimensions. Based on the principle of analogy, the research findings prove that non-mimetic creative process ("pure" action) manifests itself exclusively in connection with a human from a bodily viewpoint through anthropological mimesis, which can program the propensity to certain capabilities of the individual organism (both psychophysiological and in its creative and stylistic manifestations). C. G. Jung was the first who pointed to the productivity of this method in his work "Theoretical Reflections on the Nature of the Psyche". The creativity phenomenon (and its most specific feature - style) reflects not only "pure" psychology and the intellectual and spiritual component but also its relation to the artist as a physical being. It, outside its belonging to and being conditioned by transcendent factors, includes a quantitative aspect related to the moment of intensity. The disease (quantitative-intensive indicator) acts to some extent as a stimulator of the production/change of aesthetic enzyme ("The Obsessed" by Lesia Ukrainka). In this context, the dialectic method is also effective because the subject of study cannot be comprehensively argued using naturalistic approaches only and requires (according to A. Losev) a semantic explanation too. The essence of it is the logic of contradictions. In this case, the antinomy of matter-spirit plays a conceptual role in the projection on the plane of word-formation. Originality of the research findings is in the expansion of the causal relationship range of the creative process, namely the inclusion of the factor of psycho-physiological pathology into the system artist-work. This factor performs important stylistic functions. Conclusions. In contrast to scientific studies, where 1) style is analyzed separately (mostly in terms of text landscape description) and 2) the figure of the artist (mainly - in the parameters of empiricism, rarely - in psychoanalytic perspective), this study argues the need to correlate these issues, taking them beyond descriptiveness to avoid schematics and one-dimensionality.

Keywords: style; art; temperament; body; disease; human; artist

\section{Introduction}

Creative action is not material. It is the product of its action, which is material. However, "pure" action cannot take place beyond the artists in their bodily form. "Flesh is nothing. The spirit gives life" (authors' transl.). This well-known aphorism by H. Skovoroda is the variation of the basic question of philosophy on the primacy of the world-building principles: material and spirit. As for the creative act in its human variant, this fundamental principle sounds like this: "what is more important - psychic-spiritual factor or physical-material?". The problems of interconnection of the body and the soul form the leading direction of philosophical research, presented by the positions of Descartes and Thomas Aquinas in the European tradition (dualism in the former and integrity in the latter). Probably, one should not at all formulate the problem using or - or, since both, the matter and the spirit are primary. The position of Nobel Laureate F. Ostwald is not unfounded: "matter and to some extent even spirit is energy" (authors' transl.). Thus, we are talking about two sides of the same energy-forming process - Life (and one of its results - Culture, including literature). 
The body of the artist, as their work, is the part of the world. The soul contacts with the world through these two channels (body and work). In the process of materialization / visualization / verbalization of a writer's artifact, the figure (body) and the content (result in the form of an artistic text) are equally important. Person (artist) as a body is a super-complex system. It is either in the normal position or in a state of illness/disease. The body takes part in the creation of art product due to the temperament, which is largely caused by the structural features of the artist's body. Writer and art critic H. Wolfflin (2018) noted: "... of course, temperament does not create the artistic work, but it is the thing that can be called a material part of styles in the broadest sense of this word, that is, meaning a certain ideal of beauty (both individual and public)" (p. 27). Temperament is directly related to the disease, determining the features of its emotional and mental course, and, thus, influencing the relationship with the world (world-sensitive component of the style-creating process).

Aestheticization of the movements of their own body is common among writers. This topic (as a subject of research) appears in literary studies from time to time. The problem of diseasestyle scientists raise on occasion. S. Pavlychko (2000) dealt with it in "Nationalism, Sexuality, Orientalism: The Complex World of Agatangel Krymsky", where she remarked: "Krymsky’s nerves became the main stylistic, formative factor of his stories" (authors' transl.) (p. 57). Thus, we see that the literary critic points to the direct dependence of the novel style on the author's pathologies. Let us note that first of all it comes to the mental disorders, unlike somatic or body diseases. Doctors write about this aspect. For example, the change of the style can be traced in the manner of French painters Renoir and Toulouse-Lautrec, who were forced to move away from the Impressionist technique (Di Matteo et al., 2017). The disease restrained them, but the undeniable desire to create won: "Perhaps painting was a coping mechanism for both artists or maybe the freedom of expression can simply exceed the limits imposed by disease" (Di Matteo et al., 2017, p. 2377). It is difficult to study the relationship between the disease and the style of artistic writing, because writing requires, first of all, intellectual and expressive efforts, and only then motor-functional. Such studies relate to the ontological problems of creativity, raise the question of the psychology of creativity, reflect the combination of social and natural in it, and therefore promising in the vein of philosophical anthropology.

\section{Purpose}

Given this perspective, the purpose of the study is to continue and deepen the nonlinear approach to understanding the features of the style-creating process as the most specific word for the phenomenon of art, taking into account psychophysiological factors, including the impact of disease.

\section{Statement of basic materials}

The motif of the disease, the concept of the disease in art, particularly in literature, is persistent. This is evidenced by one of the first consciously structured speech phenomena - spells (the sphere of verbal magic). The myth is also the medium, where the basic human pathologies ferment time-space. The interpretation of ancient texts gives grounds to identify mythological characters/mythological phenomena as identical by various deviations from the norm. One of the large-scale "painful" plots is the World Flood (an attempt to cure humanity). These motives are transit, they are in all mythosystems. They are manifested, as a rule, due to bestiary imagery, astral symbolism and allegorization of natural elements. 
The phenomenon of disease in philosophical, culturological, psychological reflections appears as a concept. Literature studies is another research area addressing the problem in terms of aestheticization and participation in creative processes. Disease (of various origins) is an invariable component of sacred stories, in particular, Biblical ones, as it is one of the forms of punishment for a person who is immersed in sins and does not want to repent and return to the righteous path. The revelation of Saint John the Theologian contains just such information. The vulnerability of the mankind in terms of susceptibility to various pathologies is presented in the most famous triptych "The Garden of Earthly Delights" by Hieronymus Bosch. This canvas is ingenious for understanding the figurative embodiment of diseases, deformations, the source of which is spiritual desolation.

The history of literature and culture in general shows a constant interest in health anomalies in the broadest sense of the term, projecting it on the life of the individual, and certain social strata, and all mankind. Often the disease, which reflects the violation of the normal functioning of the organism, is extrapolated from the field of physiology to the existential, spiritual plane.

As for the literary and artistic process, the topic, the content of which is rooted in human physiology, reveals a relationship to one of the most controversial and debatable one - the nature of verbal creativity, namely to its most specific feature - style. "Speaking of the individuality of the artist, one cannot ignore the psychophysiological inclinations of a person", because they affect "the nature of the connections of this person with life and artistic material" (authors' transl.), said V. Stus (1994, p. 217).

Apart from the belonging and conditionality of the creation phenomenon by the transcendent and psychological spheres, style as a visible indicator of the peculiarities of this phenomenon contains a certain quantitative aspect (disease - excess or deficiency). The energy type of the word and lexical configurations change. Disease is a condition deforming the organism, which provokes deviations from the norm in the behavior model, causes transition of consciousness to another mode of functioning (situationally, sporadically or longer). It is appropriate to quote Lesia Ukrainka (2017): "After all, this is good that little by little, all my life I have become accustomed to imprisonment and restriction of freedom through surgery - this is capital for the future..." (authors' transl.) (p. 144). This capital is not only self-discipline, not only loneliness, but also accumulated pain, which activates the fundamental experiences - life and death, as well as their derivative - the meaning of existence. The perception of disease, in particular tuberculosis, as a capital is substantiated in the study by Sunny S. Yudkoff (2018), which is devoted, admittedly, to Jewish writers of the border period, but which organically extends to sick writers in general. The researcher develops a model of pragmatic understanding of tuberculosis, based on the relationship between the disease and creativity.

In the context of the psychology of the creativity, the problem of disease acquires a specific double effect, because being in a state of active creation is interpreted as a disease in itself, but the sacred one. Such an aspect leads to the problem of verbalizations and definitions in general. H. Nordby (2019) substantiates the philosophical argument of conceptual pluralism, which allows the existence of many concepts of disease in the communication space of producerconsumer (doctor-patient), based on the well-known speech-conventional theory of L. Wittgenstein. According to him,

...in order for two persons to express the same concept by a word like

"disease", they must be willing to defer to the same norms of meaning. 
But "disease" is a word that is used in many different language games, and speakers of one language game are often not willing to defer to the rules of other language games. (Nordby, 2019, p. 482)

The author of the study notes the attempts of the specialists to take into account the general meaning of non-obscene language, but there is no such a meaning. More specifically, the use of the words "disease", "illness", "sickness" is not limited only by the field of medicine, but also has socio-cultural connotations. Continuing the reasonings of the researcher, let us pay attention to the metaphorization of the concept "disease" and all its relatives.

An artist can be really sick (have a doctor's diagnosis), and can be "sick" with creativity, experiencing all the relevant symptoms. This is often and literally manifested in the most critical moments of the creative act: increase in blood pressure, temperature, dizziness, disorientation, anxiety, and so on.

Any disease is accompanied by painful symptoms (of varying intensity), and, hence, suffering. "Suffering is an integral part of life, as is fate and death. Without suffering and death, human life is not full" (authors' transl.) (Ukrainka, 2017, p. 82).

"Creativity is just a grimace of individual pain, and our aesthetics is the aesthetics of suffering, a little subdued pain. In the cult of suffering is the whole philosophy of art and all its greatness with the mysterious phenomena of catharsis" (authors' transl.) (Stus, 1994, p. 347). The observation belongs to V. Stus and he thinks about literary work as a "result of pain", and therefore as an abnormal phenomenon. "The art of writing, like any art, is the fruit of a special kind of excitement, which cannot be a universal norm" (authors' transl.) (Mann, 1960, p. 481).

T. Mann has a lot of statements that demonstrate his interest in the relationship between disease and creativity. In the article "Goethe and Tolstoi" the author of "Dr. Faustus" talks about the philosophy of the disease.

The disease is two-faced, it has a different attitude to human and their dignity. On the one hand, it is hostile to this dignity, because by giving preference to the bodily principle and humiliating a person only to this principle, it deprives them of the human, leaving only suffering flesh. However, on the other hand, one can imagine the disease in a different way, one can perceive it as a condition highly worthy of human. If it is an exaggeration to say that disease is a spirit and even (which would sound too tendentious) that spirit is a disease, then these two concepts are connected as closely as possible. (Mann, 1960, p. 510) 
The picture is as follows: the creativity is basically and in terms of the result (text) is almost total disease (pathology), therefore the form of verbal expression is dependent on the disease. Disease as a condition of an organism is a rebellion of an organism, an ordeal, its transfer to another mode of existence, even when the recovery comes. Spirit is also a rebellion, a rebellion against the human, too human. This is also one of the ways to reach another level, a change in the mode of perception: "Human is so much more human, the further a human departs from nature, that is, the more they are ill, the more human they are. Because what is a disease if not a break with nature?" (authors’ transl.) (Mann, 1960, p. 510).

Morbid condition is a changed condition. If the disease is in the acute state, it is, so to say, once modified picture of the world. When the disease is long-lasting, painful, abnormal factors accumulate, and this leads to character fractures, replanning the receptors. The result is a new worldview, a new world perception. Deepening into this mechanism leads to a functional aspect of the body - the moment of grouping forces. Since the body has not only a physical manifestation, but also the energetic one (aura as an opportunity to visualize the energetic state), then the disease changes this indicator in the direction of modification of emanations.

The problem "human-body" contains many subjects in its resource dimensions, which the modern science develops in the entire industry spectrum. The basic statement of the issue has the following form: the body as an idea (the context of uniformity, collectiveness) and the body as an individual form (the context of individuality, singularity). T. Boll and S. M. Müller (2020) in the process of phenomenologization of the body import the concept of "one body - one person" into the plane of the concept of "body boundary work". The study creates the field for reflections. In particular, in the context of our subject, the reflections presented give grounds to trace "How do body concepts and normativities (like the malleable, 'healthy', 'able', morbid or trainable body) correspond to typical kinds of body boundary work?" (Boll \& Müller, 2020, p. 600), how it affects the phenomenon of individuation.

We think it is appropriate to direct the conceptual continuum proposed by the authors of the cited article towards the idea of "body-creativity" (creativity in a specific style creative aspect); to reshape the problem of the "body boundary work" from the social, empirical sphere to the aesthetic one. The body in a transituational context or extreme conditions (sports, difficult childbirth, creative act) is almost another body that actually goes beyond the realm of possibility.

Transition of the receptors to a new (morbid) level of perception opens the possibility of editing the type of energy exchange of human with an environment (including surroundings). We have both the reason and the result - the reform of the physical and spiritual constitution of the subject. In our case, it is about a man-artist who is a priori sick (sick in the word), and the real physical illness deepens and strengthens the possibilities to expand and change the reception regimes.

There is another point to focus on. W. Reich (Austrian and American psychologist, neo-Freudian, one of the founders of the American school of psychoanalysis) developed a theory about the connection between the terminal disease and the character of those affected. The disease "chooses" the most suitable environment to root (the very that person), "smells" the right man. The disease is smart. As a result, perhaps for some time invisible, latent traits become dominant due to the disease. In other words, the disease exposes the essence of man. In this context, Lesia Ukrainka's tuberculosis is perhaps the disease the most "suitable" for her.

G. Bachelard said of Empedocles that he belonged to the volcano before he threw himself there. With a certain dose of probability, we assume that Lesia Ukrainka belonged to her disease before it "settled" in her, especially if we evaluate this story in the mythologizing and metaphori- 
cal parameters of tuberculosis. The moment of pre-appointment. The factor of irrational. On the other hand - volitional movement. Would Larysa Kosach have become Lesia Ukrainka, a worldclass dramatist, if not her illness? One thing is clear: this situation has shaped the will/character, raised her to the spiritual level through the body trials, and this has provided freedom of feeling and thinking. "Literature instead of morphine". "This morphine does not allow me to get dirty, sour and sleepy - thank to it for that" (authors' transl.) (Ukrainka, 2017, p. 168).

Tuberculosis was perceived as a disease of passion.

Tuberculous fever was a sign of internal burning: a tuberculosis patient is

"absorbed" by ardor, heat, which leads to body decomposition. The use

of TB-related metaphors of love - images of "morbid" love, "devouring"

passion - is long ahead of the romantic tradition. Starting from the ro-

mantics, this image was inverted, and TB began to be perceived as a var-

iant of the disease of love. (authors' transl.) (Sontag, 1978, p. 20)

According to T. Mann ("The Magic Mountain") - the symptoms of tuberculosis are nothing more than a hidden manifestation of the power of love, and the disease itself is a transformed love. Lesia Ukrainka's "The Obsessed" is an autobiographical work. Obsessed Miriam is the embodiment of absolute freedom as love, love as freedom, which is not limited by anything or anyone, not motivated by anything and not understood by anyone. Universal will, irrational force, a sign of a human worthy of their Creator.

The spirit possession is the highest expression of rebellion against the so-called natural human, a human limited "simply by the body", the most aristocratic disease that leads to real communion with God.

A number of concepts emerge, which seem to be random at first glance: the body, disease ("disease mentality" according to S. Sontag), spirit (obsession), creativity (style), character, world perception (the mode of perception, energy exchange). There is no direct connection between them, but it is at deep levels that are comprehended semantically and mentally. This situation is when "one category should be explained by another category so that one could see how one category gives birth to another and all together - one, of course, not naturalistically, but eidetically, categorically, remaining in the sphere of sense" (authors' transl.) (Losev, 1990, p. 13).

Disease and style (a way of verbal expression of thought/feeling). They do not intersect from the position of literary "empirism", because they belong to absolutely different spheres, but from the position of dialectics such connection is logical. Truth is important in any study, but often it is not illustrated, it is just there. "The whole life to the bone is dialectic, and at the same time it, the life itself, not dialectics, it is an inexhaustible, dark depth of unmanifested forms, and not the most strictly derived abstract formula" (authors' transl.) (Losev, 1990, p. 22). Artistic text as a special component of life, as its intangible extension - not formal-linguistic ability and a wellknown practical skill, especially when it comes to genes like Lesia Ukrainka-dramatist. That is a very complicated living structure with signs of "eternal engine". And disease (a modified state of the artistic text carrier) plays an important role in the energy supply of this structure. The seman- 
tics of the disease can cause changes in consciousness, and this will affect apperception in creative intentions. Tense, crisis, both physical and mental states do not go unnoticed. Aesthetic initiation can take place in an artist, because the weight and measure of words change due to redundancies (the state of the artist's body and the state of the word adequate to it). The landscape of the disease has a significant influence on the formation of the text landscape - the end result of the style-creating process, especially if the disease, so to speak, is privileged, that is, shows a connection with the spiritual aspect of human life. These include obsession. "Poet" has long been synonymous with "obsession". "The true name of the archaic poet is vates, obsessed, inspired by the gods, the one who dreams" (Huizinga, 1994, p. 139). Dreaming is not only a state of consciousness, but also of the body (the feeling of presence, control over the body is lost, it is easier, levitates, so it does not interfere, does not distract from the processes of the subtle plan).

It is quite logical that one connotational-semantic series contain "ecstasy" and "genius" (exstasy - short-term immersion of the organism in the state of excessive stress - physical and emotional - not without signs of influence in the future; genius - ecstasy, extended to existence) and obsession.

Genius as disease and disease as genius. "Disease!.. But the point is, first of all, who is ill, who is insane... mediocre fool, whose disease is devoid of spiritual and cultural aspect, or a human of Nietzsche's scale..." (authors' transl.) (Mann, 1961, p. 338). Let us modify the final phrase: or a human of Lesia Ukrainka, V. Stus' scale. We would like to develop T. Mann's opinion: it is also the point of who is ill in terms of the type of artistic nature: Apollonian or Dionysian.

For one nature, observation is typical in aesthetic behavior, and for the other - experience (empathic nature). The type of each creator/patient corresponds to its type of aesthetic state/feeling. The Apollonian inclination is equivalent to sensory, intellectual. The Dionysian primarily involves the imagination, feelings, intuition, tends to emotional freedom, including ecstasy. The Apollonian type prefers a rational balance that can reach asceticism. In one case, the aesthetic scales will lean towards tragedy (the Dionysian principle), in another - towards the ratio (what is called objectivity) - the Apollonian dominant.

The type of creative personality determines the text structure and the corresponding stylistic content of the image. If the disease stimulates the manifestation of genius with the tragic content, we will receive heightening of the perception on this basis. The burst of mental energy as a reaction of the painful nature promotes clearing of emotions from the layers of the ratio, reflexivity and "straightens" it (emotion). Expression has all chances to transform into expressionism, where emotion-feeling-state acquires an archetypal scale. According to K. Edschmid,

In this is the highest secret of this art. These artists are deprived of our

usual psychologism. At the same time, their feelings are deeper. Their

feelings choose the simplest paths, not those winding man-made ones,

not those shamed by man ways of thinking, which, guided by known

causality, can never be cosmic. (authors' transl.) (Edschmid, 1986,

p. 307)

Creative Commons Attribution 4.0 International

doi: https://doi.org/10.15802/ampr.v0i20.249502 
We can see that such a category as measure (intensity) manifests itself everywhere. As much the unit of existential-ontological area contains the disease and how long it retains the height of pain with the controlled will of self-identity, as much and in this way, it will manifest itself in style (can manifest).

There is another important factor, emphasized by V. Slapchuk in conversation with the authors on October 1, 2020 (01.27 pm). "Perhaps the determining factor is not the pain (or physical imbalance), but what motivates the writer to write. If writing for them is psychotherapy, if they sublimate certain physical problems, if they write with pain, the style will be the one. If with the same problems they try to distance themselves from suffering and implement creative ideas, the style will be another. Much depends on what creativity is for the author. To what extent (!) they are obsessed with it. To what extent is this process rational or irrational for them? What is their ultimate goal... Whether it is a confession, or reaching the level of existential, or modeling an alternative harmonious world... In any case, the mental health of the writer is more important. Undoubtedly, if the pain is present for a long time, it is at least tiring, affects the mood, or can affect the formation of worldview... Again, the level of the writer's personality (!), its formation, integrity, self-sufficiency... the pain is valuable because it is real, especially when one lives in a world of simulacra".

The volume of the citation is caused by the value of thoughts, but it is also important the fact that V. Slapchuk is one of the writers created by the pain and literature. He went through the war in Afghanistan (1979-1989) and was seriously wounded (both his legs were amputated). Long years of rehabilitation (physical and mental). The conscious choice of literature as a way of existence is connected with injuries received, and therefore with pain. About people like $\mathrm{V}$. Slapchuk, one can say that their creativity is the result of the disease (war is a collective disease, and everyone who is involved in it is a carrier of this disease in proportion to their participation). How does this influence the style, and does it influence at all? The experience of Slapchuk-writer confirms: traces of pain origin (disease) are manifested in one way or another, as the reception of reality changes, and this logically influences perception. There is a rotation (inversion plan) of visual concepts, which leads to stylistic modification by changing the size and shape of perception objects. Literary practice shows that the period of pain almost always becomes the impetus for the emergence of the texts - the carriers of pain (disease) at the stylistic level, where the energy exchange between words/rhythms with a tragic content dominates.

For Lesia Ukrainka it is "The Obsessed", for V. Stus - the collections "Time of Creativity" and "Palimpsests", for V. Drozd - the epic "Leaves of the Earth", for Lina Kostenko - the novel "Berestechko", for I. Rymaruk - poetic book "Bermuda Triangle". Each of these authors belonged to the pain even before it possessed their I. The artist is more than a human. "Human is more than the psyche" (author' transl.) (Frankl, 2019, p. 141). Style is more than an artist. Pain (disease) - more than the body. Pain (disease) has its own criteria for selecting the soil for rooting. Anyone can turn the negative of life into a construct, bringing their ego from the usual zone of self-centeredness and mental paradigms into the space of transcendence (autotranscendence the term of V. Frankl). The artist due to their talent have a unique opportunity to transform everything the world proposes them into an art form. Disease (pain, suffering) can be a trigger for the creative process, the nature of which under the normal functioning of the body would be impossible. Literary critic O. Biletsky noted a change in the stylistic features of Ivan Franko's artistic writing at the end of his life: 
Suffering and disease exacerbate Franko's nervous system and the whole spiritual structure. And in the last days of his work I feel the moments of epileptic degeneration of his spirit: the poet's ear began to open to receive a mysterious, mystical light, and his creative imagination, which resulted in the creation of the highest sculptural images, paintings of metaphorical style. This imagination is interrupted by the creative imagination (mystical, bizarre or illusory). As a result of such imaginary and creative interruptions in Ivan Franko’s poetry a new form, a form of visions, appears ... But this sign of poetic creativity not only did not reduce the value of his poetic works, but, on the contrary, raised them to a higher level, gave the ideas and images of the poet an even deeper perspective - abstractemotional and mystical. (authors’ transl.) (Biletsky, 1926, p. 231)

If one fails to mention a specific name (I. Franko), the observations about the connection of certain clinical indicators with the sources and morphology of the creative process will remain. On the one hand - disease, suffering, "exacerbated" nervous system, the psyche in a state of tension, on the other - the shift of the horizon towards the mystical (location of archetypes and symbols - the essential sphere), which provides access to the visual imagery.

Larysa Petrivna Kosach would not have become a world-class dramatist, if not for a lifelong disease. In the case of Lesia Ukrainka, it became a factor in strengthening/returning to an absolute state of freedom. Spirit/freedom and disease are intertwined. Without any logical reasons, tuberculosis became a fluctuation for Lesia Ukrainka, which initiated the formation of qualitatively new worldview structures capable of resisting comprehensive enslavement by revising values. The thing that limits (disease) caused liberation, unlocked the space of "pure" freedom = "pure" humanity: "the genius of disease is more human than the genius of health..." (authors' transl.) (Mann, 1960, p. 510). Lesia Ukrainka in a letter to O. Kobylianska expressed her understanding of the situation, fertilized by the complications. This understanding concerns a specific episode in the life of O. Kobylianska, but at the same time reveals Lesia Ukrainka's (2017) position on such moments in general: "... Who has the strength to walk on a sharp stones, will always go through it to something high, higher than one can usually come on smooth and even paths" (authors' transl.) (p. 303).

"Smooth and even paths" would not lead to "The Obsessed". It is safe to say that this work by Lesia Ukrainka would not have been written outside the context of the disease (similar to a continuous ordeal) that became "capital" on the basis of which an existence with the potential of ob- 
session as freedom was built, which implies the power of personal experience on a scale of universal. The period of pain (S. Merzhinsky's disease), during which the text of the poem was formed, became a turning point. "The Obsessed" can be interpreted as a bifurcation point: the parameters of the art system have acquired new stylistic features - expressionist.

\section{Originality}

The study of the influence of psychophysiological factors, in particular disease, on the change of the style of artistic writing makes it possible to deepen the interpretation of the creative process and to rethink the cause-effect range of its driving forces. The proposed method opens new prospects for research on the problems of literary creativity in the aspect of philosophical anthropology.

\section{Conclusions}

Are the diseases and style clearly connected with cause-effect relationship? In our opinion, the state of the organism as a complex system (it is about long-term ordeals and suffering) cannot but affect the style, because the style is, at least, a person.

The disease reformats the artist's $I$ based on pain. Value attitudes are changing towards approaching the essential. The essence lies in the plane of fundamental laws, which include the law of the fight of Good and Evil. The tension reaches the registers of tragedy. Thus, at the level of style, an aggregation (moreover, the frequency of use increases) of imagery formations takes place, which are used to express the way to the essence through suffering (historically, this is the most effective way to gain spiritual experience, which opens communication channels). Fundamentally, the style of expressionism is the closest to such a transformation chain, as well as naturalism close to it (there is a term to denote the expressionist stylistic structure, which contains the moment of naturalism gradation in its guiding principle - transcendental naturalism).

Is the disease necessary to activate the creative process and its forming in the text? Definitely not. Will the disease cause the need for adequate deviation/deformation of the body word form? As a rule, yes. At least sporadically, at the level of one work, which will become a milestone. The history of literature presents a number of names in which genius is inseparable from the disease, fused with it (as T. Mann said about F. Nietzsche): G. Trakl, G. Kaiser, F. Kafka, V. Stefanyk, Lesia Ukrainka, V. Drozd. Disease as a state of the body and the style are two dimensions of the artist's phenomenon that correlate.

\section{REFERENCES}

Biletsky, L. (1926). Khto takyi Franko dlia ukrainskoho narodu? Literaturno-naukovyi vistnyk, 90(7-8), $226-232$. (in Ukrainian)

Boll, T., \& Müller, S. M. (2020). Body Boundary Work: Praxeological Thoughts on Personal Corporality. Human Studies, 43(4), 585-602. DOI: https://doi.org/10.1007/s10746-020-09555-2 (in English)

Di Matteo, B., Tarabella, V., Filardo, G., Tanzi, P., Kon, E., Iacono, F., \& Marcacci, M. (2017). Art in Science: The Artist and The Disease: The Exemplary Cases of Renoir and Toulouse-Lautrec. Clinical Orthopaedics and Related Research, 475(10), 2376-2381. DOI: https://doi.org/10.1007/s11999-017-5458-7 (in English)

Edschmid, K. (1986). Ekspressionizm v poezii. In Nazyvat veshchi svoimi imenami: Programmnye vystupleniya masterov zapadno-evropeyskoy literatury 20 veka (pp. 300-316). Moscow: Progress. (in Russian)

Frankl, V. (2019). Man's Search for Meaning. Kharkiv: Family Leisure Club. (in Ukrainian)

Huizinga, J. (1994). Homo Ludens. Kyiv: Osnovy. (in Ukrainian)

Losev, A. (1990). Iz rannikh proizvedeniy. Moscow: Pravda. (in Russian) 
Mann, T. (1960). Sobranie sochineniy (Vol. 9). Moscow: State Publishing House of Fiction. (in Russian)

Mann, T. (1961). Sobranie sochineniy (Vol. 10). Moscow: State Publishing House of Fiction. (in Russian)

Nordby, H. (2019). Who Are the Rightful Owners of the Concepts Disease, Illness and Sickness? A Pluralistic Analysis of Basic Health Concepts. Open Journal of Philosophy, 9(4), 470-492. DOI: https://doi.org/ 10.4236/ojpp.2019.94029 (in English)

Pavlychko, S. (2000). Natsionalizm, seksualnist, oriientalizm: Skladnyi svit Ahatanhela Krymskoho. Kyiv: Osnovy. (in Ukrainian)

Sontag, S. (1978). Illness as Metaphor. New York: Farrar, Straus and Giroux. (in English)

Stus, V. (1994). Tvory (Vol. 4). Lviv: Publishing Union "Prosvita". (in Ukrainian)

Ukrainka, L. (2017). Lysty: 1898-1902. Kyiv: Komora. (in Ukrainian)

Wolfflin, H. (2018). Osnovnye ponyatiya istorii iskusstv. Problema evolyutsii stilya v novom iskusstve. Moscow: Yurayt. (in Russian)

Yudkoff, S. S. (2018). Tubercular Capital: Illness and the Conditions of Modern Jewish Writing. Stanford: Stanfofd University Press. (in English)

\section{LIST OF REFERENCE LINKS}

Білецький Л. Хто такий Франко для українського народу? Літературно-науковий вістник. 1926. Т. 90. Кн. 7-8. C. 226-232.

Boll T., Müller S. M. Body Boundary Work: Praxeological Thoughts on Personal Corporality. Human Studies. 2020. Vol. 43. Iss. 4. P. 585-602. DOI: https://doi.org/10.1007/s10746-020-09555-2

Di Matteo B., Tarabella V., Filardo G., Tanzi P., Kon E., Iacono F., Marcacci M. Art in Science: The Artist and The Disease: The Exemplary Cases of Renoir and Toulouse-Lautrec. Clinical Orthopaedics and Related Research. 2017. Vol. 475. Iss. 10. P. 2376-2381. DOI: https://doi.org/10.1007/s11999-017-5458-7

Эдшмид К. Экспрессионизм в поэзии. Называть вещи своими именами : Прогр. выступления мастеров запад.-европ. лит. ХХ в. / сост. Л. Г. Андреева. Москва : Прогресс, 1986. С. 300-316.

Франкл В. Людина в пошуках справжнього сенсу. Харків : Клуб сімейного дозвілля, 2019. 160 с.

Гейзінга Й. Ното Ludens. Київ : Основи, 1994. 250 с.

Лосев А. Из ранних произведений. Москва : Правда, 1990. 655 с.

Манн Т. Собрание сочинений : в 10 т. Москва : Государственное издательство художественной литературы, 1960. T. 9. $686 \mathrm{c.}$

Манн Т. Собрание сочинений : в 10 т. Москва : Государственное издательство художественной литературы, 1961. T. 10. 696 c.

Nordby H. Who Are the Rightful Owners of the Concepts Disease, Illness and Sickness? A Pluralistic Analysis of Basic Health Concepts. Open Journal of Philosophy. 2019. Vol. 9. Iss. 4. P. 470-492. DOI: https://doi.org/ 10.4236/ojpp.2019.94029

Павличко С. Націоналізм, сексуальність, орієнталізм: складний світ Агатангела Кримського. Київ : Основи, 2000.328 c.

Sontag S. Illness as Metaphor. New York : Farrar, Straus and Giroux, 1978. 87 p.

Стус В. Твори : у 4 т., 6 кн. Львів : Видавнича спілка "Просвіта", 1994. Т. 4.544 с.

Українка Л. Листи: 1898 - 1902 / упоряд. В. А. Прокіп (Савчук). Київ : Комора, 2017. 544 с.

Вёльфлин Г. Основные понятия истории искусств. Проблема эволюичии стиля в новом искусстве. Москва : Юрайт, 2018. 296 с.

Yudkoff S. S. Tubercular Capital: Illness and the Conditions of Modern Jewish Writing. Stanford : Stanfofd University Press, 2018. 256 p.

\section{Г. І. ЯСТРУБЕЦЬКА ${ }^{1 *}$, Т. П. ЛЕВЧУК ${ }^{2 *}$}

1* Волинський національний університет імені Лесі Українки (Луцьк, Україна), ел. пошта iastrubetska.galina@vnu.edu.ua, ORCID 0000-0003-1470-9232

${ }^{2 *}$ Волинський національний університет імені Лесі Українки (Луцьк, Україна), ел. пошта Tereza.Levchuk@vnu.edu.ua, ORCID 0000-0002-0277-3280 


\section{Психофізіологія митця в диспозиції до стилю (з використанням матеріалів біографії Лесі Українки)}

Мета наукової розвідки - з'ясувати та обгрунтувати роль психофізіології в творчім процесі, а саме корекцію стилю у зв'язку з патологічними змінами в організмі митця, відійшовши від емпіричнодескрипційних методів. Теоретичний базис дослідження - в потрактуванні стилю і хвороби не в їх вузько фаховому обмеженні, а в погляді 3 позиції розширення параметрів цих понять до філософських вимірів. На основі принципу аналогій подаються міркування про те, що неміметична творча дія ("чиста" дія) проявляється винятково у зв'язку з людиною тілесною через антропологічний мімезис, який може програмувати схильність до таких чи інакших можливостей індивідуального організму (як у психофізіологічних, так і в творчо-стильових проявах). На продуктивність цього методу вказав уперше К. Г. Юнг у "Теоретичних міркуваннях щодо природи психічного". Творчий феномен (і його найбільш питома властивість - стиль) відбиває не лише "чисту" психологію та інтелектуально-духовну складову, але й презентує стосунок до митця як фізичної істоти. Він (творчий процес), поза приналежністю і зумовленістю трансцендентними чинниками, включає кількісний аспект, пов'язаний з моментом інтенсивності. Хвороба (кількісноінтенсивний показник) виступає певною мірою стимулятором вироблення / зміни естетичного ферменту ("Одержима" Лесі Українки). У цьому контексті дієвим $є$ також діалектичний метод, оскільки предмет вивчення не може бути вичерпно аргументований за допомогою натуралістичних підходів і потребує (за О. Лосєвим) чисто смислового пояснення, суть якого полягає в логіці протиріч. У цьому випадку концептуальну роль відіграє антиномія матерія-дух у проєкції на площину словотворчості. Наукова новизна отриманих результатів полягає у розширенні причинно-наслідкового діапазону творчого процесу: включення фактора психофізіологічної патології в систему митеиь-твір як наділеного важливими стильовими повноваженнями. Висновки. На тлі наукових розвідок, де відокремлено аналізуються: 1) стиль (здебільшого в аспекті дескрипції текстового ландшафту); 2) постать митця (в основному - в параметрах емпірики, рідко у психоаналітичному ракурсі). Це дослідження аргументує необхідність кореляції названих моментів, виведення їх за межі описовості задля уникнення схематичності та одновимірності.

Ключові слова: стиль; творчість; темперамент; тіло; хвороба; людина; митець

Received: 23.03.2021

Accepted: 25.11.2021 